\title{
Differential Effect of Ethidium Bromide and Cytosine Arabinoside on Mitochondrial and Nuclear DNA Synthesis in HeLa Cells
}

\author{
Kenzo Kato *, Klaus D. RadsaK **, and Hilary KoprowsK \\ The Wistar Institute of Anatomy and Biology, 36th and Spruce Streets, \\ Philadelphia, Pennsylvania 19104 \\ (Z. Naturforsch. 27 b, 989—991 [1972] ; received April 19/May 6, 1972)
}

\begin{abstract}
The effect of ethidium bromide (EB) on the synthesis of circular DNA of mammalian cells was studied by isopycnic centrifugation in a CsCl-EB solution. EB $(0.1-0.5 \mu \mathrm{g} / \mathrm{ml})$ interferes with the synthesis of newly-formed circular DNA of HeLa cell mitochondria and causes degradation of the pre-existing circular DNA, as well. Under the same conditions, nuclear DNA synthesis was not inhibited. This effect was not reversible at a concentration of $0.5 \mu \mathrm{g} \mathrm{EB} / \mathrm{ml}$ or more. Cytosine arabinoside (ara-C) did not exhibit an effect similar to that of EB.
\end{abstract}

Recently we have observed that ethidium bromide (2,7-diamino-10-ethyl-9-phenyl-phenanthridium bromide) (EB) at concentrations of $0.1 \mu \mathrm{g} / \mathrm{ml}$ or more inhibits the incorporation of ${ }^{3} \mathrm{H}$-thymidine into the circular double-stranded DNA of mitochondria in HeLa cells ${ }^{1}$. The question arose whether EB only inhibits the synthesis of the newly-formed circular DNA of mitochondria or also degrades pre-existing circular DNA. The reversibility of the EB effect was another point to be clarified. Of importance also was a comparison of the effect of EB with that of cytosine-arabinoside (ara-C).

\section{Materials and Methods}

Cells: M HeLa cells were grown as monolayer cultures in double-strength Eagle's Basal Medium (2X BME) supplemented with $10 \%$ fetal calf serum (FCS).

Chemicals: EB was purchased from Calbiochem, Los Angeles, Calif., ${ }^{3} \mathrm{H}$-thymidine (specific radioactivity, $20 \mathrm{C} / \mathrm{mmole}$ ) and ${ }^{14} \mathrm{C}$-thymidine (speciefic radioactivity, $24.5 \mathrm{mC} / \mathrm{mmole}$ ), from New England Nuclear, Boston, Mass., and cytosine-arabinoside from Sigma Chemical Company, Missouri.

Extraction of mitochondrial DNA, centrifugation conditions, and measurement of radioactivity: Crude preparations of mitochondrial DNA of HeLa cells were obtained by the extraction method using $1 \%$ sodium dodecyl sulfate (SDS) and $100 \mu \mathrm{g}$ predigested pronase per $\mathrm{ml}$ and by the fractionation procedure described by HIRT ${ }^{3}$. Isopoycnic centrifugation of the supernatant was performed in a $\mathrm{CsCl}$ solution containing $100 \mu \mathrm{g}$ $\mathrm{EB} / \mathrm{ml}$ (mean density, 1.550) for $24 \mathrm{~h}$ at $43,000 \mathrm{rev} /$ min at $20^{\circ}$ (see ref. ${ }^{3}$ ) using at 50 fixed-angle rotor in a Beckman Model $\mathrm{L}_{2}$ centrifuge. Nuclear DNA was extracted as described previously ${ }^{5}$.

Requests for reprints should be sent to Dr. K. RADSAK, Hygiene Institute, D-3550 Marburg/Lahn, Pilgrimstein 2, W.-Germany.
The fractions were collected from the bottom of the gradients and precipitated on millipore filters $(0.45 \mu)$ with cold trichloracetic acid as described previously ${ }^{1}$. The radioactivity was measured in a Beckman liquid scintillation counter using a toluene - Liquiflour (New Englang Nuclear) mixture.

\section{Results}

Effect of EB on the circular DNA of HeLa cell mitochondria: Previous experiments showed that EB inhibits the synthesis of newly-formed circular mitochondrial DNA in HeLa cells ${ }^{1}$. To examine whether it also acts on pre-existing circular DNA, we labeled approximately $5 \times 10^{6} \mathrm{HeLa}$ cells with ${ }^{14} \mathrm{C}$-thymidine $(1.0 \mu \mathrm{C} / \mathrm{ml})$ for $48 \mathrm{~h}$. The medium was then changed, and the cells were exposed to ${ }^{3} \mathrm{H}$-thymidine $(5 \mu \mathrm{C} / \mathrm{ml})$ and $\mathrm{EB}(0.5 \mu \mathrm{g} / \mathrm{ml})$ for an additional $48 \mathrm{~h}$. No EB was added to the control culture. After a total incubation period of $96 \mathrm{~h}$, the mitochondrial DNA was extracted by the SDS-pronase method described by HIRT ${ }^{3}$.

If $\mathrm{EB}$ interfered only with the synthesis of newlyformed circular DNA, ${ }^{14}$ C-labeled, covalently-closed, circular, double-stranded DNA would be detectable by isopycnic centrifugation in a CsCl-EB solution. If, however, EB also degraded pre-existing circular DNA, no radioactivity should occur in the position of double-stranded circular DNA.

In the control samples, a clear radioactivity peak was obtained for ${ }^{3} \mathrm{H}$ and ${ }^{14} \mathrm{C}$ in the region of the circular mitochondrial DNA (Fig. 1 a), whereas in the EB-treated samples no specific radioactivity peak was exhibited in this region (Fig. $1 \mathrm{~b}$ ).

The total ${ }^{3} \mathrm{H}$-radioactivity of circular DNA region in the EB-treated sample was $3.2 \%$ of that in the 


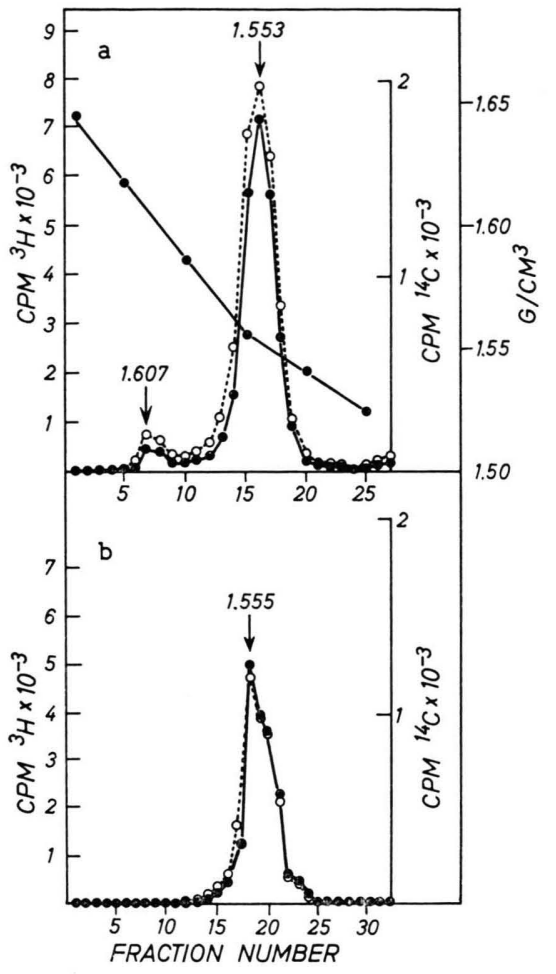

Fig. 1. Degradation of pre-existing mitochondrial DNA of HeLa cells by EB. Isopycnic centrifugation in a CsCl-EB solution was performed on a crude preparation of mitochondrial DNA, (a) extracted from $5 \times 10^{6} \mathrm{HeLa}$ cells labeled for $48 \mathrm{~h}$ with ${ }^{14} \mathrm{C}$-thymidine $(1.0 \mu \mathrm{C} / \mathrm{ml})(-\bullet)$, and for another $48 \mathrm{~h}$ with ${ }^{3} \mathrm{H}$-thymidine $\left.(5 \mu \mathrm{C} / \mathrm{ml})(0 \cdots \circ) ; \mathrm{b}\right)$ extracted from $5 \times 10^{6} \mathrm{HeLa}$ cells labeled with ${ }^{14} \mathrm{C}$-thymidine $(1.0 \mu \mathrm{C} /$ $\mathrm{ml})$ for $48 \mathrm{~h}$ and exposed to ${ }^{3} \mathrm{H}$-thymidine $(5 \mu \mathrm{C} / \mathrm{ml})$ and $\mathrm{EB}$ $(0.5 \mu \mathrm{g} / \mathrm{ml})$ for the following $48 \mathrm{~h}$. The lighter fraction of linear double stranded DNA represents nuclear DNA fragments contaminating the crude preparation of mitochondrial DNA after SDS-pronase extraction from $\mathrm{HeLa}$ cells according to HIRT ${ }^{3}$. Centrifugation conditions: CsCl-EB $(100 \mu \mathrm{g} / \mathrm{ml})$; mean density, 1.55; 50 fixed-angle rotor; $43,000 \mathrm{rev} / \mathrm{min}$; $24 \mathrm{~h} ; 20^{\circ} \mathrm{C}$. The buoyant densities $(-\bullet)$ of circular and linear DNA are 1.607 and $1.553 \sim 1.5555 \mathrm{~g} / \mathrm{cm}^{3}$, respectively.

\begin{tabular}{lcc}
\hline $\begin{array}{l}\text { Treatment of cells } \\
{[\mu \mathrm{g} \mathrm{EB} / \mathrm{ml} \text { for } 48 \mathrm{~h}]}\end{array}$ & \multicolumn{2}{c}{$\begin{array}{c}\text { Total radioactivity }\left({ }^{3} \mathrm{H}\right) \text { of } \\
\text { circular DNA fraction }\end{array}$} \\
& net counts $/ \mathrm{min}$ & $\%$ control \\
\hline 0.5 & 669 & 3.2 \\
Control & 27,076 & 100
\end{tabular}

Table 1. Inhibition of Synthesis of Closed-Circular Mitochondrial DNA in HeLa Cells by Ethidium Bromide.

Total ${ }^{3} \mathrm{H}$-radioactivity of circular double-stranded DNA is calculated from CsCl-EB gradient shown in Fig. 1.

control, and for ${ }^{14} \mathrm{C}$-radioactivity, $8.2 \%$ (Tables 1 and 2). This result indicated that EB not only inhibits newly-synthesized circular DNA, but also degrades pre-existing circular DNA.

\begin{tabular}{lcc}
\hline $\begin{array}{l}\text { Treatment of cells } \\
{[\mu \mathrm{g} \mathrm{EB} / \mathrm{ml} \text { for } 48 \mathrm{~h}]}\end{array}$ & \multicolumn{2}{c}{$\begin{array}{c}\text { Total radioactivity }\left({ }^{14} \mathrm{C}\right) \text { of } \\
\text { circular DNA fraction }\end{array}$} \\
& net counts/min & \% control \\
\hline 0.5 & 26 & 8.2 \\
Control & 316 & 100 \\
\hline
\end{tabular}

Table 2. Degradation of Pre-Existing Closed-Circular Mitochondrial DNA in HeLa Cells by Ethidium Bromide.

Total ${ }^{14} \mathrm{C}$-radioactivity of circular double-stranded DNA is calculated from CsCl-EB gradient shown in Fig. 1.

Reversibility of the effect of EB: To examine whether the effect of $\mathrm{EB}$ is reversible, we exposed $5 \times 10^{6} \mathrm{HeLa}$ cells to concentrations of 0.1 or $0.5 \mu \mathrm{g}$ $\mathrm{EB} / \mathrm{ml}$ of culture medium for $48 \mathrm{~h}$. The medium was then changed and the cells were continuously labeled with ${ }^{3} \mathrm{H}$-thymidine $(5 \mu \mathrm{C} / \mathrm{ml})$ for an additional $48 \mathrm{~h}$. The mitochondrial DNA was then extracted by the SDS-pronase method of $\mathrm{HIRT}^{3}$ and analyzed by isopycnic centrifugation in a $\mathrm{CsCl}-\mathrm{EB}$ solution.

Limited radioactivity was obtained in the position of circular double-stranded DNA. In this case the total radioactivity for the circular DNA region in the EB-treated samples was $22.4 \%(0.1 \mu \mathrm{g} \mathrm{EB} / \mathrm{ml})$ and $9.6 \%(0.5 \mu \mathrm{g} \mathrm{EB} / \mathrm{ml})$ of the control (Table 3$)$.

\begin{tabular}{|c|c|c|}
\hline \multirow[t]{2}{*}{$\begin{array}{l}\text { Treatment of cells } \\
{[\mu \mathrm{g} \mathrm{EB} / \mathrm{ml} \text { for } 48 \mathrm{~h}]}\end{array}$} & \multicolumn{2}{|c|}{$\begin{array}{l}\text { Total radioactivity }\left({ }^{3} \mathrm{H}\right) \text { of } \\
\text { circular DNA fraction }\end{array}$} \\
\hline & net counts/min & $\%$ control \\
\hline 0.1 & 4,723 & 22.4 \\
\hline 0.5 & 2,016 & 9.6 \\
\hline Control & 21,076 & 100 \\
\hline
\end{tabular}

Table 3. Reversibility of the Effect of Ethidium Bromide.

Total radioactivity of circular double-stranded DNA is calculated from CsCl-EB gradient (not given here). Mitochondrial DNA was extracted from HeLa cells after exposure to 0.1 or $0.5 \mu \mathrm{g} \mathrm{EB} / \mathrm{ml}$ of culture medium for $48 \mathrm{~h}$. The medium was then changed and the cells were exposed to ${ }^{3} \mathrm{H}$-thymidine $(5 \mu \mathrm{C} / \mathrm{ml})$ for the following $48 \mathrm{~h}$.

Comparison of the effect of EB with that of cytosine-arabinoside: To ascertain the specificity of the action of EB, the effect of cytosine-arabinoside was examined in the same system. The compound was added simultaneously with ${ }^{3} \mathrm{H}$-thymidine $(5 \mu \mathrm{C} / \mathrm{ml})$ to the culture medium of approximately $5 \times 10^{6} \mathrm{HeLa}$ cell monolayer cultures. After $48 \mathrm{~h}$, the mitochondrial DNA was extracted and analyzed by isopycnic centrifugation in a CsCl-EB solution.

As shown in Fig. 2, at the chosen concentrations cytosine-arabinoside $(10 \mu \mathrm{g} / \mathrm{ml})$ did not exhibit an effect similar to that of EB. In contrast to EB, which 


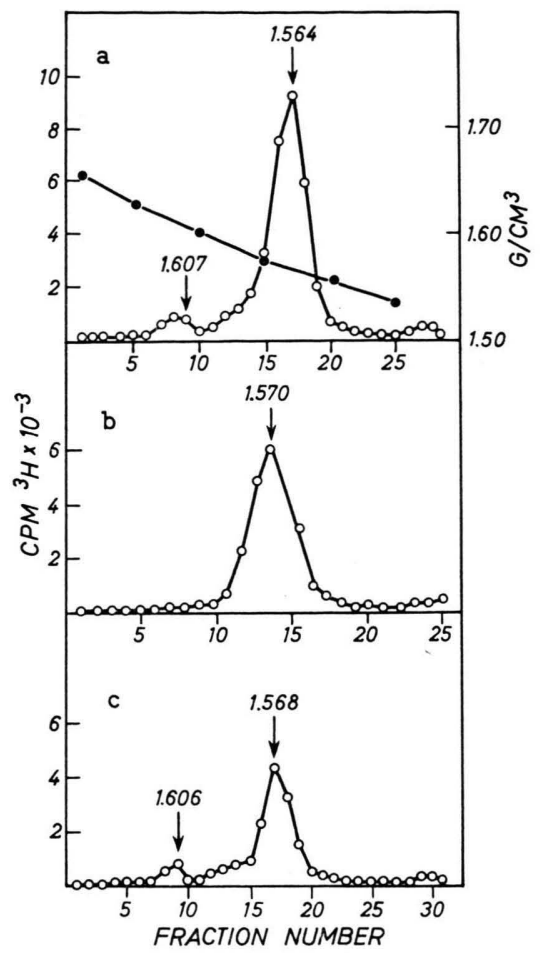

Fig. 2. Effect of EB and cytosine-arabinoside on the synthesis of mitochondrial DNA in HeLa cells. Isopycnic centrifugation in an CsCl-EB solution was performed on mitochondrial DNA, (a) extracted from $5 \times 10^{6} \mathrm{HeLa}$ cells labeled with ${ }^{3} \mathrm{H}$-thymidine $(5 \mu \mathrm{C} / \mathrm{ml})(\mathrm{O}-\mathrm{O})$ for $48 \mathrm{~h}$; (b) extracted from $5 \times 10^{6}$ $\mathrm{HeLa}$ cells labeled with ${ }^{3} \mathrm{H}$-thymidine for $48 \mathrm{~h}$ and simultaneously exposed to $0.5 \mu \mathrm{g} \mathrm{EB} / \mathrm{ml}(\mathrm{O}-\mathrm{O})$; (c) extracted from $5 \times 10^{6} \mathrm{HeLa}$ cells labeled with ${ }^{3} \mathrm{H}$-thymidine $(5 \mu \mathrm{C} / \mathrm{ml})$ for $48 \mathrm{~h}$ and simultaneously exposed to cytosine-arabinoside $(10 \mu \mathrm{g} / \mathrm{ml})(0-0)$. Centrifugation conditions: CsCl-EB $(100 \mu \mathrm{g} / \mathrm{ml}) ;$ mean density $1.55 ; 50$ fixed-angle rotor; 43,000 $\mathrm{rev} / \mathrm{min} ; 24 \mathrm{~h} ; 20^{\circ} \mathrm{C}$. The buoyant densities (- - ) of circular DNA are 1.607 (a) and 1.606 (b), of linear DNA 1,564 (a), 1.570 (b), 1.568 (c). The linear DNA fraction represents contaminating nuclear DNA fragments (see legend Fig. 1).

strongly inhibits the synthesis of mitochondrial DNA, but does not affect that of nuclear DNA, cytosinearabinoside strongly inhibited the nuclear DNA synthesis (Table 4) and slightly the mitochondrial DNA synthesis (Fig. 2 c). In Fig. 2 c, most of the radioactivity in the region of linear DNA $(\varrho=1.568)$ may be explained by the observation that cytosinearabinoside causes a large amount of degradation of nuclear DNA (unpublished data).

1 K. Radsak, K. Kato, Y. Sato, and H. Koprowski, Exp. Cell Res. 66, 410 [1971].

2 L. Hayflick, Exp. Cell Res. 37, 614 [1965].

3 B. HiR T, J. molecular Biol. 26, 365 [1967].

4 R. Radloff, W. Bauer, and J. Vinograd, Proc. nat. Acad. Sci. USA 57, 1514 [1967].

\begin{tabular}{lcc}
\hline $\begin{array}{l}\text { Treatment of cells } \\
{[\mu \mathrm{g} / \mathrm{ml} \text { for } 48 \mathrm{~h}]}\end{array}$ & $\begin{array}{l}\text { Specific radioactivity of } \\
\text { nuclear DNA as \% control }\end{array}$ \\
\hline Ethidium bromide & 1.0 & 94 \\
& 0.5 & 116 \\
Cytosine- & 10 & 1 \\
arabinoside & 1 & 14 \\
Control & & $100 *$ \\
\hline
\end{tabular}

Table 4. Comparison of the Effects of EB and CytosineArabinoside on the Synthesis of Nuclear DNA in HeLa Cells.

* Mean calue, 2196 counts $/ \mathrm{min}{ }^{3} \mathrm{H} / \mu \mathrm{g}$ DNA.

Specific radioactivity $(\mathrm{cpm} / \mu \mathrm{g}$ DNA) of nuclear DNA of HeLa cells labeled with ${ }^{3} \mathrm{H}$-thymidine $(5 \mu \mathrm{C} / \mathrm{ml})$ for $48 \mathrm{~h}$ and simultaneously treated with EB or cytosine-arabinoside was determined.

\section{Discussion}

Our results show that EB interferes differentially with the synthesis of closed circular double-stranded DNA of mitochondria in HeLa cells. It also degrades preexisting circular DNA. These effects are not reversible during the time period observed.

The action of EB, therefore, cannot be explained by the specific inhibition of the mitochondrial DNA polymerase alone ${ }^{6}$. Its effect may also be the consequence of a degradation of the circular DNA, caused by direct interaction between DNA and EB ${ }^{4}$. The degradation might furthermore result from an indirect action of EB on the circular DNA by the inactivation of repair enzymes or activation of endonucleases. Further experiments are needed to elucidate this result.

In any case differential inhibition of the synthesis of circular DNA of mitochondria with EB could be a useful tool in studying the as-yet-unknown relation between nuclear- and mitochondrial-DNA-directed apparatus of the cell. Investigations in this direction are in progress.

This investigation was supported, in part, by US Public Health Service Research Grants R01-CA 04534, P01-CA 10815 and R01-Ca 10028 from the National Cancer Institute and S01-RR 05540 from the General Research Support Branch.

The authors are grateful to Dr. Frantisek Sokol and Dr. David KritchevsKY of The Wistar Institute for their helpful criticism in this work.

5 K. Berns and C. A. Thomas, JR., J. molecular Biol. 11, 476 [1965].

6 R. R. Meyer and M. V. Simpson, Biochem. biophysic. Res. Commun. 34, 238 [1969]. 